\title{
The Navel, Reflections on the composition of the Quarta pars Digestorum
}

\author{
W.J. Zwalve \\ Professor of Legal History, Faculty of Law, Leiden University, Leiden, \\ The Netherlands \\ wjzwalve49@gmail.com \\ Th. de Vries \\ Professor of Methods and Data, Faculty of Research Methodology, \\ Measurement and Data Analysis, Twente University, Enschede, \\ The Netherlands \\ tdevries@wxs.nl
}

\section{Summary}

In an earlier edition of Tijdschrift voor Rechtsgeschiedenis we have contended that Justinian's Digest was composed on the basis of Ulpian's Libri ad Edictum and the peculiarities and special exigencies of the legal curriculum. It was also contended that the distribution of the fifty books over the seven partes of the Digest was based on a mathematical formula, complicated by the fact that Justinian (Tribonian) had decided to assign four books to the first pars (Ta prota) and 36 to the first five partes together according to 'the nature and science of numbers' (natura et ars numerorum). This article offers some additional arguments supporting our thesis and concentrates on the composition of the quarta pars Digestorum, designated by Justinian himself as 'The Navel' (Umbilicus) of the entire composition. The hypothesis is that Tribonian composed the quarta pars Digestorum as a microcosm of the Digest as a whole and that he has been 'juggling with numbers' within the composition of 'The Navel' as he has ostensibly done in the composition of the Digest as a whole.

\section{Keywords}

composition of Justinian's Digest - legal curriculum - partes Digestorum - Umbilicus - numerology 


\section{Umbilicus}

In our previous article ${ }^{1}$ we have contended that Justinian's Digest was composed on the basis of Ulpian's Libri ad Edictum on the one hand and the peculiarities and special exigencies of the legal curriculum on the other. The arrangement of the text of the Digest over seven partes originated in educational practices current in Roman law schools long before Justinian. In Justinian's new legal curriculum readings from Ulpian's Libri ad Edictum still dominated the classroom, since this commentary was the mainstay of the first three partes of the Digest - Ta Próta (Dig. Book 1-4), De iudiciis (Dig. Book 5-11) and De rebus (Dig. Book 12-19) - that were mandatory reading in the first, second and third year of the study of the law ${ }^{2}$. Apart from readings ad Edictum from Ulpian's commentary, the old legal curriculum prevailing before the introduction of Justinian's new program consisted of three other components. Leaving aside the introductory course on Gaius's Institutiones in the first year and the final course on imperial legislation in the fifth and last year, it contained a pars Sabiniana (readings from Ulpian's ad Sabinum, consisting of four 'monographs' (libri singulares))3; a pars Papiniana (readings from Papinian's Responsa) and a pars Pauliana (private reading of Paulus's Responsa) ${ }^{4}$. Justinian (Tribonian) retained most of these elements of traditional legal education ${ }^{5}$ and concentrated it in the fourth and fifth pars of the Digest. The quinta pars was entirely dedicated to two of the four 'monographs' (libri singulares) from the pars Sabiniana students had to read under the old legal curriculum. It contained the law of wills and was composed of a book De testamentis in two parts (De testamentis libri duo (D. 28-29)) and a book De legatis et fideicommissis in seven parts (De legatis et fideicommissis libri septem (D. 30-36)). All the other components were concentrated in the Umbilicus, the quarta pars Digestorum ${ }^{6}$. It is composed of six Libri singulares and one book in two parts.

The five last books of Umbilicus (D. 23-27) contained an extended version of two of the four libri singulares read in the last semester of the first year in the old curriculum, De re uxoria and De tutelis ${ }^{7}$. In the Digest these two libri

1 The new temple, TvR 85 (2017), p. 492-521.

2 Const. Omnem $\S \S 2-4$.

3 Const. Omnem $\S 1$ : 'libri singulares quattuor, primus de illa vetere re uxoria, secundus de tutelis et tertius nec non quartus de testamentis et legatis'.

4 Const. Omnem $\S 1$.

5 Most, though not all: Paulus lost his special place in the curriculum. See our previous article (supra, n. 1) at p. 5 o1.

6 Const. Tanta $\S 5$ : 'totius compositionis quasi quidam umbilicus'.

7 Const. Omnem $\S 1$ : 'libri singulares quattuor, primus de illa vetere re uxoria, secundus de tutelis et tertius nec non quartus de testamentis et legatis'. 
TABLE 1 Contents of Umbilicus

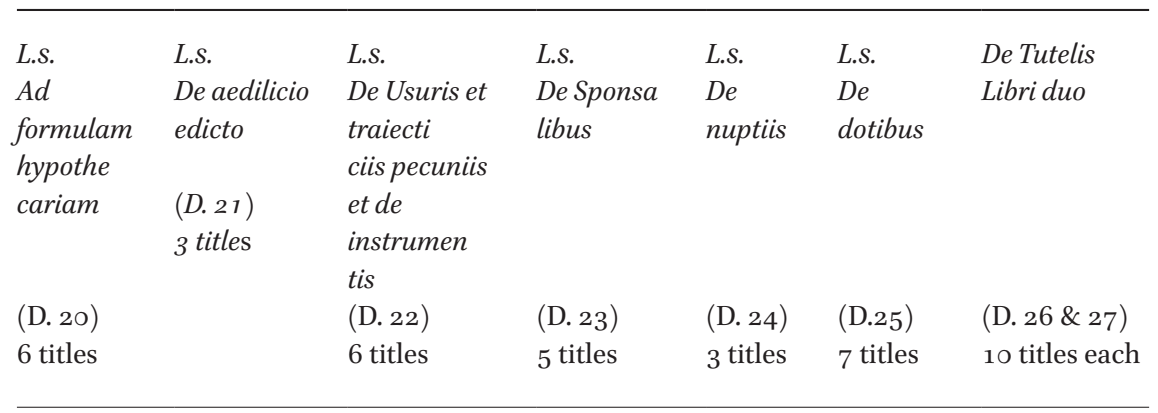

singulares were replaced by three libri singulares on the law of marriage and one book in two parts on wardship 8 . In the new curriculum the first liber singularis on marriage law (D. 23) and the first book on the law of wardship (D. 26) were to be read in the second half of the second year ${ }^{9}$, that is after the mandatory course De iudiciis or De rebus was completed ${ }^{10}$. Consequently, students who entered their third year were already acquainted with some of the contents of Umbilicus. What was new to them, however, were the first three books of that pars. It was here that Justinian (Tribonian) introduced a novelty and contrived his famous bellissima machinatio ${ }^{11}$.

\section{The 'Antipapinianum' and the 'bellissima machinatio'}

In the old curriculum, third year students were styled as Papinianistae ${ }^{12}$, since it was in that year that they were introduced to the writings of Papinian in classes on the Responsa of that vir sublimissimus. The first class of these Papinianistic readings was even a special feast day in the curriculum ${ }^{13}$. Not only because students were by now, after having read the first three partes of

$8 \quad$ Const. Tanta $\S 5$ : 'Post hos si qua de sponsalibus vel nuptiis vel dotibus legibus dicta sunt reposuimus, tribus librorum voluminibus ea concludentes'.

$9 \quad$ Const. Omnem $\S 3$ : 'ex collectione quidem tripertiti voluminis, quod pro dotibus composuimus, uno libro excerpto. Ex duobus autem de tutelis et curationibus uno'.

10 In addition to that, the first book of De testamentis (D. 28) and De legatis (D. 30) from the quinta pars were to be read in the second year as well: (Const. Omnem $\S 3$ ) 'et ex gemino volumine de testamentis uno: et ex septem libris de legatis et fideicommissis et quae circa ea sunt simili modo uno tantum libro'.

$11 \quad$ Const. Omnem $\S 4$.

12 Const. Omnem $\S 4$ : 'tertii anni auditores, quos Papinianistas vocant'.

13 Const. Omnem $\S$ 4: 'festum diem, quem, cum primum leges eius accipiebant, celebrare solebant'. 
Ulpian's libri ad edictum, considered worthy of the privilege of reading Papinian, but also (and not in the least) because they were now exactly halfway their study and beginning with the last course on ancient jurisprudence (ius) to be taught in classes by a professor. We know that under the old curriculum only eight out of the nineteen books of Papinian's Responsa were actually read in the third year and, says Justinian, even these only piecemeal ${ }^{14}$. Our guess is that a prominent part of what was indeed read at that time was about the law of security interests, as dealt with by Papinian in the 11th book of his Responsa. All this explains Justinian's bellissima machinatio. The emperor wanted to retain the ancient tradition of giving a prominent position to Papinian in the third year of the curriculum, after the completion of the classes ad Edictum as contained in the first three partes of the Digest. Accordingly, he prescribed that, after the completion of the classes on the partes De iudiciis and De rebus, that is after the first semester of the third year, the first three books of Umbilicus should be read during the remainder of that year, beginning with what he styled as the Liber singularis ad formulam hypothecariam (D. 20) ${ }^{15}$. The rubrics of the titles of the Liber singularis ad formulam hypothecariam in the Digest were copied from Justinian's Codex ${ }^{16}$, since it was a guiding principle in the composition of the Digest that it should follow the arrangement of the Codex (and the Edictum perpetuum $)^{17}$. But whereas the Codex has more than 20 titles dealing with security interests in Book 8 , the subject is condensed into no more than six titles in D. 20. All except the third title begin with a text from Papinian's Responsa or his Quaestiones ${ }^{18}$. This is what is generally regarded as the essence of Tribonian's bellissima machinatio. In reality, however, that machinatio goes much deeper than that.

Tribonian regarded the first three books of Umbilicus as a distinct and special unit within that pars Digestorum, to be read, in its entirety, at a special place in the curriculum, the last semester of the third year. He repeatedly sets it against the 'compositio quattuordecim librorum', being the remaining five books of Umbilicus (D. 23-27) and the two compositiones on wills and legacies

14 Const. Omnem § 1: 'ex praedicta responsorum consummatione, quae decimo et nono libro concludebatur, octo tantummodo libros accipiebant, nec eorum totum corpus eis tradebatur, sed pauca ex multis et brevissima ex amplissimis'.

15 Const. Omnem $\S 4$ : 'in primis liber singularis ad hypothecariam formulam'.

16 See C. 8,13 for the rubrica of D. 20,1; C. 8,14 for the rubrica of D. 20,2; C 8,16 for D. 20,3; C. 8,17 for D. 20,4 ; C. 8,27 for D. 20,5 and C. 8,3 o for D. 20,6 .

17 Const. Deo auctore $\S 5$ : 'totum ius digerere, tam secundum nostri constitutionum codicis quam edicti perpetui imitationem'.

18 D. 20,1,1 (Papinianus, libro undecimo Responsorum); D. 20,2,1 (Papinianus, libro decimo Responsorum); D. 20,4,1 (Papinianus, libro octavo Quaestionum); D. 20,5,1 (Papinianus, libro vicesimo sexto Quaestionum); D. 20,6,1 (Papinianus, libro undecimo Responsorum). 
(De testamentis and De legatis) in the pars quinta (D. 28-36) ${ }^{19}$. This is why the law professors of the Justinian age, especially Stephanus and Julian (of Epitome fame), referred to it with a special epithet, 'to Antipapinianon', meaning the book that comes 'as a substitute for Papinian', and numbered the contents of it separately (referring, for example, to Book 20 as 'the first book of the Antipapinianum') as if it were indeed a distinct pars Digestorum ${ }^{20}$. In the composition of the 'Antipapinianum' Tribonian consciously disregarded the two guiding principles for the composition of the Digest as a whole, the arrangement of the Codex Justinianus and the Edictum perpetuum (read: Ulpian's libriad edictum) ${ }^{21}$. In the pars De rebus (D. 12 - 19) he had closely followed the arrangement of the fourth book of Justinian's Codex and the pars De rebus of Ulpian's commentary Ad edictum (Ulp. Aded., book 26 - 32). That order was interrupted by the insertion of the 'Antipapinianum'.

The first book of the 'Antipapinianum' (D. 20) deals with the formula hypothecaria, which was commented on by Ulpian only in book 73 of his commentary Ad edictum and by Papinian in the 11th book of his Responsa ${ }^{22}$. In

19 See Const. Omnem $\S 3$ : 'ex omni compositione quattuordecim librorum' and $\S 5$ (twice). Tribonian stresses that the sum of all the libri singulares contained in the Umbilicus and the pars De testamentis is seventeen: (Const. Omnem, $\S 5$ ) 'decem et septem libros partitus (...) quem in duabus digestorum partibus posuimus, id est quarta et quinta, secundum septem partium distributionem'. This number (17) may not have been unintentional, since, as Saint Augustine testifies (In Joannis evangelium 21,8, Migne PL 35, col. 1963), it is the sum of 10 (the Ten Commandments, the Law) and seven (the Holy Spirit (septenario numero significatur Spiritus sanctus, Saint Augustine, l.c.). It is the root of the modern antithesis of the 'letter of the law' and the 'spirit of the law'. We cannot interpret the Law without the aid of the Holy Spirit, since without that aid, says St. Augustine, 'the letter destroys' (littera occidit): 'accedat ergo ad litteram (10) spiritus (7), ne occidat littera quem non vivificat spiritus'. Medieval jurists were well aware of this, since it was usual for them to begin their consilia with a prayer. For the number 7 representing the Holy Spirit see also Isidore of Seville (56o-636), Liber numerorum qui in sanctis scripturis occurunt, 8,39 (Migne PL 83, col. 187): 'convenienter itaque septenario numero significatur Spiritus sanctus', a clear citation from St. Augustine.

20 See the references in Heimbach's Prolegomena (Vol. vi of his edition of Basilicorum Libri $L X$, Leipzig 1870, repr. (with an introduction by H.J. Scheltema) Amsterdam 1962), p. 22 and n. 10; Scheltema, Subseciva, III: Die Verweisungen bei den frühbyzantinischen Rechtsgelehrten, TvR 30 (1962), p 355-357 (now also in H.J. Scheltema, Opera Minora, Groningen 2004, p. 116-118 (117)) and in the new edition of Julian's paratitla to his Epitome by Nico van der Wal, Subseciva Groningana, II (1985), p. 93-137 (103, r. 25): 'in primo titulo Antipapiniani'. See also infra at n. 37 .

21 Const. Deo auctore $\S 5$ : 'totum ius digerere, tam secundum nostri constitutionum codicis quam edicti perpetui imitationem'.

22 The most frequently cited text in D. 20, however, is neither of these, but Marcianus's $A d$ formulam hypothecariam, which explains why Tribonian assigned a special place to this book by letting the third title of book 20 begin with a fragment from Marcianus's book. 
Justinian's Codex the subject of security interests is only dealt with in the eighth book. Tribonian justifies this discontinuity in the general order of arrangement by emphasizing the necessity to deal with security interests, and the formula hypothecaria in particular, at a location in the Digest not too far distant from the actio pigneraticia, which had been dealt with in the pars De rebus (D. 13,7 $)^{23}$. He uses the same argument defending the insertion of D. 21, the Liber singularis de aedilicio edicto, into the 'Antipapinianum'. The matter of aedilician actions was indeed dealt with in book 4 of Justinian's Codex (C. 4,58), but the closely related subject of evictions only in the eighth book $($ C. 8,44). Ulpian, for his part, had inserted a commentary De aedilicio edicto only as an appendix to his commentary Ad edictum (Ulp., Ad ed. 82-83), whereas he had indeed dealt with the matter of evictions and stipulationes duplae in the $32 n d$ book Ad edictum and in his commentary on the aedilician edict (Ulp., Ad ed. 83), but more extensively in the 29th book of his commentary Ad Sabinum. Tribonian decided to move this subject forward (and to insert the relevant passages from Ulpianus's commentary Ad Sabinum in the process) ${ }^{24}$ in order to connect it more closely to the subject of sale, which had been dealt with in the pars De rebus (D. 18 and 19,1 $)^{25}$. The triad of the 'Antipapinianum' was completed by a Liber singularis De Usuris et traiecticiis pecuniis et de instrumentis (D. 22), at first sight a rather odd mixture of dispositions on the law of interest (D. 22,1 and 2) and the law of evidence (22,3-5), but on second thoughts a proper conclusion to the law of contracts dealt with in the pars De rebus

There are 12 extended fragments from Marcianus's Ad formulam hypothecariam and 10 more or less lengthy fragments from the 73rd book of Ulpian's commentary Ad edictum in D. 20. The most frequently cited author in D. 20, however, is Paulus (22 fragments), but from various different works (Responsa, Quaestiones, Ad edictum, Sententiarum, Ad Plautium, De officio praefecti vigilii, and his Decreta). Some of the references to works by Paulus in Book 20 are, moreover, mere insertions into a text of Marcianus (as in D. 20,1,12) or of Ulpianus (as in 20,1,7), proving that he was a secondary source for the composition of D. 20.

23 Const. Tanta § 5: 'ut non a pigneraticia actione in libris de rebus posita multum distarent'.

24 The relevant passages in Ulpianus's commentary ad Sabinum were well known to the professors in Tribonian's drafting committee, since they had used them in their courses on Ulpianus's commentary Ad edictum. Cross-references to Ulpianus's commentary $A d$ Sabinum in classes on his commentary Ad edictum and to his commentary Ad edictum in classses on (parts of) his commentary Ad Sabinum were frequent in the old curriculum. See our previous article (supra, n. 1), p. 495-50o.

25 Const. Tanta $\S 5$ : 'alio libro eodem inserto volumine, quae aedilicium edictum et redhibitoriam actionem et duplae stipulationem, quae de evictionibus proposita est, continet. Quia haec omnia titulis emptionum et venditionum consentanea sunt et praedicta actiones quasi pedisequae illarum ab initio processerunt, in vetustioris quidem edicti ordinatione in loca devia et multo distantia devagantes, per nostram autem providentiam his congregatae, cum oportuerat ea quae de eodem paene loquuntur in confinio ponere'. 
(creditis) since it is concerned with the main consequence of default on the part of a debtor (mora), i.e. his obligation to pay interest over the sum due to his creditor, and with the means to give evidence of a contract ${ }^{26}$.

The 'Antipapinianum' stands out in the Digest, not just by the rather cheap trick commonly regarded as Tribonian's bellissima machinatio, i.e. by the fact that all but one (D. 20,3,1 (Marcianus)) of the six titles in Book 20 begin with a fragment from the writings of Papinian, but also because it is the only distinct unit within the Digest having a perfectly harmonious composition: 6 (Book 20) +3 (Book 21) +6 (Book 22) titles ${ }^{27}$. This is the bellissima machinatio Tribonian himself must have had in mind, because it refers to the number $36(2 \times 6 \times 3)$, signifying 'perfection'28 in contemporary Greek numerology 29 , thus making

26 The last title of D. 22 (D. 22,6, De iuris et facti ignorantia) is a conundrum. Paulus had written a treatise on the subject under that title and the matter had been dealt with in the first book of Justinian's Codex (C. 1,18). It seems out of place in this section of the Digest, that is at the end of a title on the law of interest and the law of evidence. A more suitable location to deal with error would have been in the previous book on aedilician actions (D. 21), since they are primarily concerned with cases of mistake on the part of a vendee. The compilers of Justinian's Codex, however, seem to have been more concerned with error iuris than with mistake (error facti), since they allocated the subject to C. 1,18 , that is immediately following the titles on the sources of law (C. 1,14-17). See on this issue also infra, n. 29 .

27 The amount of titles in the 'Antipapinianum' has been manipulated in order to achieve this symmetry as is evident in the curious composition of the second title of D. 21 (De evictionibus et duplae stipulatione). D. 21,2 consists of two consecutive titles: D. 21,2,1-12 contains an original title De evictionibus, corresponding with the title De evictionibus in Justinian's Codex (C. 8,44(45)), whereas D. 21,2,13 - 76 represents another title De duplae stipulatione, a rubric occurring in Ulpian's commentary Ad Sabinum on the law of emptio venditio (Ulpianus ad Sabinum 29, Lenel, Palingenesia II, col. 1123). The two titles were deliberately combined, as is expressed in the rubric itself (De evictionibus ET duplae stipulatione), but why? Bluhme ('Die Ordnung der Fragmente in den Pandectentiteln: Ein Beitrag zur Entstehungsgeschichte der Pandecten', Zeitschrift für geschichtliche Rechtswissenschaft, 4 (1820) p. 301-302) is rather vague, if not reticent, about the reason for this fusion of two titles into one. We suggest it was done because of the numerical constraint Tribonian was under to compose the 'Antipapinianum' in a 'perfect' Neopythagorean composition of $6+3+6$ titles, and, of course, in order not to surpass the predetermined number of 50 titles for the entire Quarta pars. A similar phenomenon occurs in the composition De re uxoria: see infra fnt. 48.

28 According to a contemporary of Tribonian, and also a member of Justinian's bureaucracy,

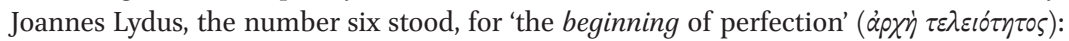
Lydus, De mensibus 1,17 (ed. Wünsch, Leipzig 1898, 10). Consequently, the 'Antipapinianum' had to begin with a book consisting of six titles. Lydus's book on the months of the year is full of numerological exercises. Tribonian wrote a similar book $\Pi \varepsilon p i \mu \eta \nu \hat{\omega} \nu$ in epic verses (Suda $\tau 957$ (Tpıßuviavós), ed. Adler, I, 4, Leipzig 1935, 588). On the identity of this Tribonian see our previous article (supra, n. 1), p. 514, n. 94, and infra n. 46.

29 For a lucid introduction into this obscure subject see Vincent Foster Hopper, Medieval number symbolism, New York 1938. If our suggestion that the 'Antipapinianum' was for 
the 'Antipapinianum' the 'quintessence' of the Digest as a whole ${ }^{30}$. The special position of the 'Antipapinianum' is also emphasised by the way it has been dealt with codicologically in the oldest manuscript of the Digest existent, the Codex florentinus.

\section{A closer look at the composition of Umbilicus in the Codex Florentinus}

When one takes a closer look at the Codex florentinus, it turns out that each of the three units of Umbilicus - the 'Antipapinianum' (Book 20-22); the three books on marriage law (Book 23-25) and the two books on wardship (Book 2627 ) - consists of a set of quires clearly separated from each other in the same way as is usually only done with the larger units within the Digest, i.e the seven larger partes it is composed of ${ }^{31}$. Each of the three units of Umbilicus represents, as it were, a pars on its own. Book 20 starts at fol. 288 recto, being the first

numerological purposes composed of 6,3 and 6 titles is right, this may perhaps help to explain the curious addition of the title De iuris et facti ignorantia in D. 22,6. As was observed earlier (supra, n. 26), a more proper place for this subject would have been in D. 21, but that book may have been (if, again, our suggestion is right) predetermined to contain three titles only, so there was no room for it there. Without the title De iuris et facti ignorantia, D. 22 would have contained only five titles, since Tribonian was clearly done with the law of evidence comprised in D. $22,3-5$, as these three titles corresponded with the three titles on this subject in the Codex (C. 4,19-21). He was able to sustain the harmonious composition of the 'Antipapinianum' by adding the title De iuris et facti ignorantia to D. 22 as the 6 th title of that book.

30 See for the number 36 signifying 'perfection' in contemporary Greek numerology Hopper, Medieval number symbolism (supra, n. 29), p. 45 and the references in our previous article (supra, n. 1), p. 512, n. 89. See also Pseudo-Iamblichus (Anatolius), Theologoumena

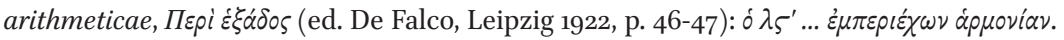
We were tempted to add a reference to the composition of the first title of Book 20 as an additional argument. In Mommsen's edition it consists of 35 leges. It turns out, however, that there are 36 in the Codex florentinus, since at what is now (in Mommsen's edition) D. 20,1,34,1 the Florentina (fol. 291 recto) clearly has a new lex beginning with 'idem quaesiit'. Since there is no indication here of a book and the number of that book, Mommsen and others have treated this as an error of the scribe and have inserted this text into D. 20,1,34 (Scaevola), thus leaving the first title of Book 20 with 35 rather than 36 leges. All other 'idem quaesiit'-fragments from the Digesta of Scaevola in the Digest are indeed treated as paragraphs rather than as separate leges (see for example D. 12,6,67,3; 33,2,32, 3 and 4; 34 pr.; 33,2,36,1; 33,5,21; 33,7,20,4 'und sonst öfters'). Mommsen's assumption may, therefore, be correct and excludes this phenomenon as an argument. It is curious though that this mistake (if it is one) is only made once in the entire Digest.

31 Bernard Stolte, The partes of the Digest in the Codex Florentinus, Subseciva Groningana, 1 (1984), p. 69-91 (71-77) was first to draw attention to this curious phenomenon. 
page of a new set of quires (xxx-xxxiii) ${ }^{32}$ comprising the 'Antipapinianum'. It ends at fol. 321 verso with an entire blank page, thus indicating a clear break with the other unit on marriage law beginning with Book 23, the liber singularis De Sponsalibus, at fol. 322 recto, the first page of a new set of quires (xxxiv). Within the 'Antipapinianum' itself there are no such breaks. Book 21 starts at f. 297 verso, whereas a new quire (xxxi) begins at fol. 298 recto, in the middle, that is, of D. 21,1,1,9 (Ulpianus). The whole set was written by one and the same scriptor (no vi, by Mommsen's count) ${ }^{33}$.

The three books De re uxoria (Book 23 - 25) contained in the Umbilicus are also bundled in one separate set of four quires (xxxiv - xxxvii), written by one scribe (no V). It starts at fol. 322 recto (D. 23,1) and ends at fol. 357 verso, an almost blank page but for D. 25,7,3 - 5. The two books De tutelis (Book 26-27) begin at $f .358$ recto, being the first page of a new set of quires (xxxviii). Within the three books De re uxoria there are, again, no such clear breaks. Book 23 ends at $f .336$ verso with almost half of that page left blank, but the beginning of D. 24 at fol. 337 recto is not marked by the beginning of a new quire, whereas Book 25 begins at fol. 351 verso. The two books De tutelis (Book 26-27) are treated similarly. Book 26 starts at fol. 358 recto with a new quire, as does Book 27 , beginning with a new quire (xl) at fol. 378 recto. Book 27 ends at fol. 396 verso with more than half of that page left blank. The next page, fol. 397 recto, has the beginning of the fifth pars of the Digest (De testamentis, D. 28 - 36) and starts with a new quire (xlii), as is usual with the beginning of a new pars of the $D i$ gest $^{34}$. Both books (26 and 27) were written by the same scriptor (no III), probably because of his special expertise in Greek, since book 27 contains large sections of Modestinus's De excusationibus, a book written in Greek ${ }^{35}$.

The codicological composition of Umbilicus in the Codex florentinus corresponds with the way contemporary Justinian law professors referred to each of the constituent parts it was composed of. Thalelaeus ${ }^{36}$ refers to D. 20 (the Liber

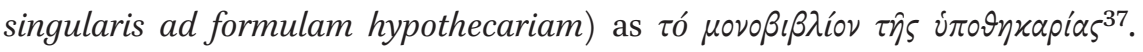

32 The quires of the Florentina are numbered and are to be found at the bottom of the first page of each quire.

33 See Mommsen's table in the Praefatio of his edition of the Digest at xxviiii.

34 Except for the last pars. The transition from the sexta to the septima pars, i.e. from D. 44 to D. 45 , is the only instance in the Codex florentinus where a change of pars is not marked by a clear separation in the manuscript. See on this phenomenon our previous article (supra, n. 1), p. 517 .

35 Mommsen, Praefatio at xxxvi, drawing attention to the fact that scribe III also wrote Const. Dedoken.

36 He was one of the professors the Const. Omnem was addressed to.

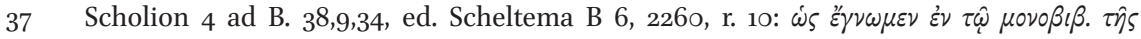

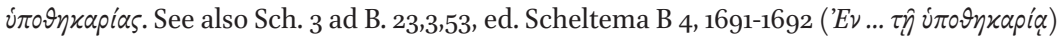


Stephanus, however, who read law in the last years of Justinian's reign, refers to it as "the first book of the "Antipapinianum"38, thus emphasizing that D. 20

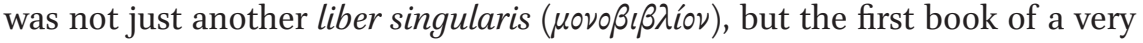

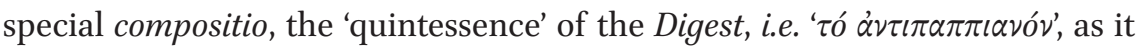
was usually called. The three libri singulares De re uxoria (D. 23-25) were less consistently referred to as parts of a distinct compositio ${ }^{39}$, but here it is Thalelaeus who clearly does so. He refers to D. 23 as 'the first book on dowries' ( $\tau$ ó

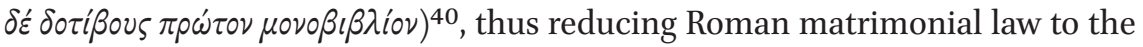
only issue of real importance, the dowry (dos). Similarly, both Thalelaeus and

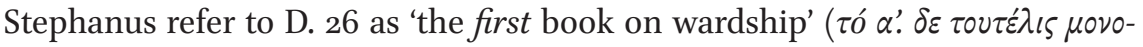
$\beta(\beta \lambda i o v)^{41}$. So, what we have in Umbilicus is a carefully arranged pars Digestorum containing three distinct compositiones, two consisting of three books each and one of two books. It is our contention that this careful arrangement was carried through in the distribution of titles over the three components of Umbilicus.

\section{Juggling with numbers again}

By deliberately fixing the number of titles of all books contained in Umbilicus at fifty, Tribonian created exactly the same problem of distribution as with the distribution of books over the seven partes of the Digest as a whole, since the total number of books of the Digest was fixed by Justinian himself at fifty as well. In the latter case, the problem was complicated by the fact that the

and Theodorus in Sch. 1 ad B. 12,1,84, ed. Scheltema B 2, 533, r. 18 ( $\dot{\varepsilon} \nu \tau \hat{\eta} \nu v \pi 0 \tau \nu \varepsilon \beta \alpha$ pía ino:nxapía). For further references see Heimbach, Prolegomena, p. 21, n. 8 and Scheltema, Subseciva, III, TvR 30 (1962), p. 355-357 (356), n. 6 (Opera minora, p. 117).

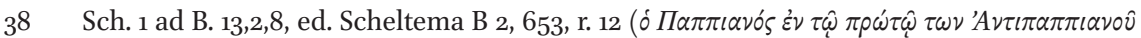
$\mu \circ v 0 \beta \iota \beta \lambda i \omega \nu \tau \imath \tau . \beta$. $\delta \imath \gamma . \alpha^{\prime} .(=$ D. $\left.20,2,1)\right)$ and the references supra, n. 20 . See also Sch. 45 ad

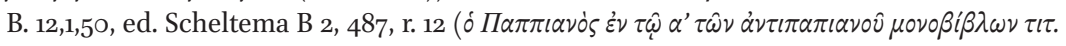
$\alpha^{\prime} \delta\left(\gamma \cdot \alpha^{\prime}(=\mathrm{D} .20,1,1)\right)$, a scholion attributed to the elder Anonymus, who lived and worked between 540 and 560 and wrote a Greek Summa of the entire Digest.

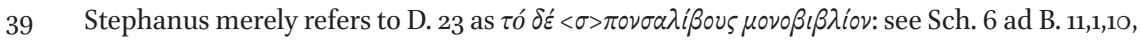
ed. Scheltema B 1, 218, r. 33. For further references see Heimbach, Prolegomena, p. 22, n. 14 and Scheltema, Subseciva III, TvR 30 (1962), p. 355-357 (357), n. 10 (Opera minora, p. 118).

40 Sch. 4 ad B. 11,1,67, ed. Scheltema B 1, 315, r. 5-6. For further references see Heimbach, Prolegomena, p. 22, n. 13 and Scheltema, Subseciva III, TvR 30 (1962), p. 355-357 (356), n. 19 (Opera minora, p. 118).

41 See Sch. 1 ad B. 38,1,86, ed. Scheltema B 6, 2193, r. 18-19 and especially Sch. 2 ad B. 38,9,18, ed. Scheltema B 6, 2255, r. 15-16: 'the first book on wardship, which is the 26 th of the entire

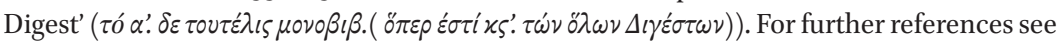
Heimbach, Prolegomena, p. 22-23, n. 15 . 
amount of books contained in the initial pars of the Digest, Ta prota, was predetermined at four (D. 1-4), since it was meant as an 'elementary' course, in addition to the elementary four books of the Institutes, to be taught in the first year as well. The problem was even more complicated by the fact that the the total amount of books contained in the first five partes of the Digest was fixed at $36^{42}$. In the case of the distribution of titles over Umbilicus, the problem was complicated by Justinian's bellissima machinatio, since it implied that the 'Antipapinianum' was predetermined to contain 15 titles, distributed over three books at a ratio of 6,3 and 6 titles each, thus creating the problem of how to distribute the remaining 35 titles over the two remaining units of Umbilicus, being the books De re uxoria and De tutelis. It should be emphasised in this context that neopythagorean philosophy, if it may be called thus, was not only about the nature of numbers, but also about 'the symmetries resulting from them'43. The composition of the 'Antipapinianum' may serve as an illustration. It is about the hexad (6) and the triad (3), but also about the symmetry resulting from these numbers in the harmonious triangular structure of D. $20-22$. Tribonian now faced the problem of how to achieve a more or less harmonious structure for the rest of Umbilicus which was in compliance with 'the nature and science of numbers' (natura et ars numerorum) ${ }^{44}$.

The number 35 - the total amount of titles yet to be distributed over the remaining five books of Umbilicus - has four divisors: 1, 5, 7 and itself. The first two ( 1 and 5 ) and the last (35) are no option, which leaves us with 7 and a resulting even allocation of seven titles to each of the five remaining books. Tribonian did not do this. Instead of that, he assigned the only possible divisor of 35 to only one of the five remaining books, D. 25 . This is a remarkable choice, since D. 25 is the third book in a progression of five. It is the mean, 'the navel of the navel' as it were, taking into account that the composition of the 'Antipapinianum' was to be set apart as a distinct unit of $6+3+6$ titles. It is also the book that closes the first half of the Digest as a whole and was therefore of

42 On all these issues and Tribonian's solution to this problem of distribution see our previous article (supra, n. 1), p. 510-514.

43 See 'Pseudo-Plutarchus' (Aetius, 1st century AD), De placitis philosophorum, 1,3,8 (in Plutarchus, Moralia, V, (ed. Bernardakis, Leipzig 1893, p. 270-271) and H. Diels, Doxographi graeci, Berlin 1879, p. 280-281): 'Pythagoras the Samian, the son of Mnesarchus, from another origin deduces the principles of all things; it was he who first gave philosophy its name. He assigns the first principles to be numbers, and those symmetries resulting from

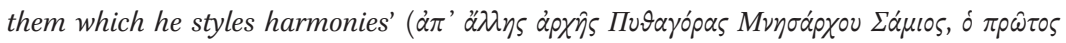

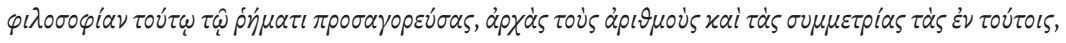

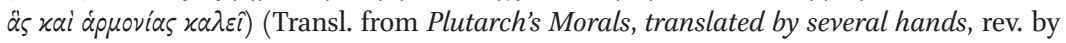
William W. Goodwin, III, Boston 1878, p. 109) (emphasis added). 
special significance and deserving of attention. Hence the seven titles of D. 25, a reference to the seven partes of the Digest, thus repeating the reference to the Digest as a whole by the allocation of 50 titles to Umbilicus itself, representing all the books of the Digest.

The number 35 ('the fifth heptad, harmonic $\left.35^{\prime}\right)^{45}$ is also a composite number with o $\mathrm{n} \mathrm{y}$ two factors, 5 and 7 . The last number, seven, was assigned to D. 25 and the first of the factors of 35 , five, was chosen for the amount of titles

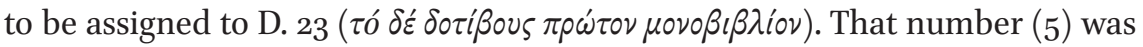
most appropriate as the beginning of a treatise De re uxoria, certainly so for a 'numerologist' as Tribonian clearly was ${ }^{46}$. According to the third-century mathematician and theologian Anatolius, the number 5 binds to each other a male and female number' ( 3 and 2 ; odd numbers are male, even numbers female) and is therefore called 'nuptial'( $(\gamma \alpha \mu \eta \lambda i \alpha)$ ': 'The pentad is the first number to encompass the specific identity of all number, since it encompasses 2 , the first even number, and 3 , the first odd number. Hence it is called 'marriage', since it is formed of male and female ${ }^{\prime 4}$. After having thus fixed the amount of titles to be attributed to the first and the last book of the trilogy De re uxoria at 5 and 7 respectively ${ }^{48}$, there was only one obvious solution left for the amount

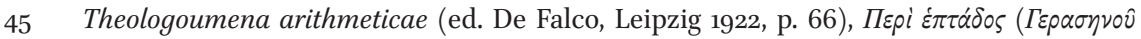
$N(x \circ \mu \dot{\alpha} \chi 0 v): \dot{\eta} \varepsilon^{\prime} \dot{\varepsilon} \beta \delta o \mu \alpha \dot{s}, \dot{o} \alpha \dot{p} \mu \circ v\left(x o ́ \varsigma \lambda \varepsilon^{\prime}\right.$. The Theologoumena contains excerpts from a book on arithmetic and numerology by the famous neopythagorean mathematician Nicomachus of Gerasa (6o-12O AD) and from a book by the third century mathematician Anatolius (bishop of Laodicea c. 280), whom Eusebius (Historia ecclesiastica 7,32,6) praises for his extensive knowledge of arithmetic, geometry and astronomy. The Theologoumena was later attributed to Iamblichus (c. 242-327 AD) and the remarkable book survived in the collections of his writings.

46 For the identity of Tribonian, the compiler of the Digest, and the polymath from Side, mentioned in Suda $\tau 957$ (ed. A. Adler, Suidae Lexicon, Leipzig 1928-1938, I, 4, 588) see H.J. Scheltema, Over getallen in het Corpus Iuris Civilis, in: E. Alkema (ed.), Vrijheid en recht, Opstellen aangeboden aan prof. mr E.H. 'sJacob, Zwolle 1975, p. 227-228 (now in Opera Minora p. 395-396) and our previous article (supra, n. 1), p, 514, n. 94. Honoré, Tribonian, London 1978, p. 64-69, was led astray by a misinterpretation of Suda $\tau 957$.

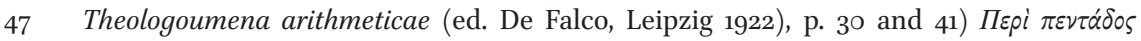

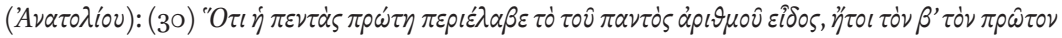

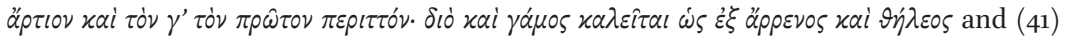

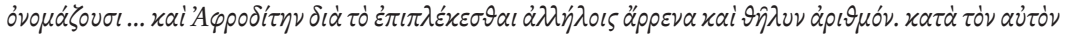
$\delta \dot{\varepsilon} \tau$ то́то to Iamblichus, translated by Robin Waterfield, Michigan 1988, p. 65 and 73-74.

48 As in the 'Antipapinianum' (see supra fnt. 27), the amount of titles of the composition De re uxoria has been deliberately manipulated. Here it is D. 23,2 (De ritu nuptiarum) that also contains a duplication ('Verdoppelung') of the Bluhmian 'Massen': D. 23,2,1-51 corresponds with the title De nuptiis in the Codex (C. 5,4) and D. 23,2,52-68 with the title De incestis nuptiis in the Codex (C. 5,5), showing that an entire title has been suppressed 
The basic Pythagorean 'tetraktys' and the first four triangular numbers

1

2

3

4

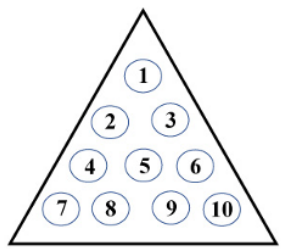

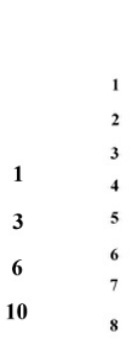

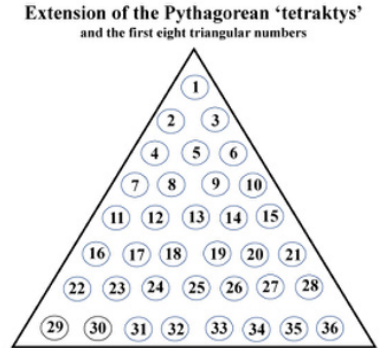

FIGURE 1 Extensions of the famous Pythagorean 'tetraktys'

of titles to be assigned to the mean, D. 24, to wit three, since it was the only way to sustain a quasi-symmetrical equilibrium between the structure of the first and second compositio of Umbilicus, each composed of three books and each consisting of fifteen titles. This exercise left Tribonian with 20 titles to be distributed over the two remaining books of Umbilicus, the Libri duo de tutelis.

Tribonian reveals a propensity for triangular numbers in the solution of the distributional problem of Umbilicus, especially so in the composition of the 'Antipapinianum'. Triangular numbers are the basic concept of neopythagorean numerology, since they are by definition extensions of the famous Pythagorean 'tetraktys' $(1+2+3+4=10)$ as is shown in Figure 1.

He had indeed chosen two non-triangular numbers, 5 and 7, for D. 23 and D. 25 , but only for special purposes: the number five for D. 23 , in order to indicate the subject of that book, the first of three De re uxoria, and the number seven for D. 25 as a reference to the seven partes of the Digest as a whole. For the total amount of titles to be assigned to the three libri de re uxoria, he chose a triangular number (15), as he had done for that very emblem of perfection, the 'Antipapinianum', where he had employed two other triangular numbers ( 3 and 6) as well. This left him with the obvious choice of yet another triangular

and fused with a previous title. Bluhme thought that the title De incestis nuptiis ('eine ohnehin nicht sehr logische Abtheilung') was suppressed 'weil manche Fragmente so gut in den einen, als in den andern Titel passen mußten' (Bluhme, 'Ordnung' p. 300). This is a rather gratuitous assessment. We suggest it was done to hold on to the predetermined number of 50 titles in all for the entire Quarta pars and also in order not to disturb the ingenuous distribution of titles over D. 23 at a ratio of 5,3 and 7. A consecutive duplication of all three 'Massen' (Sabinian, Edict and Papinian) in one title is an extremely rare phenomenon in the Digest. Bluhme ('Ordnung', p. 299-302) registers only three other instances: D. 32 (De legatis); D. 1,3 (De legibus) and D. 34,2 (De auro argento mundo ornamentis unguentis veste vel vestimentis et statuis legatis). The fact that two of the five instances in total occur within the relatively short space of two succeeding compositiones in Umbilicus is hardly coincidental. 
number, the 'decad' $(10)^{49}$, as the solution for the distribution of the remaining 20 titles over the two books De tutelis (D. 26 and 27) and in the process creating another symmetrical structure for the final composition of Umbilicus.

\section{Conclusion}

Neopythagorean number symbolism and the arithmetic involved thrived in late antiquity, certainly so among Christian theologians, impressed as they were by the extensive use the Jewish theologian Philo of Alexandria (c. 20 BC-c. $50 \mathrm{AD}$ ) had made of it in his De specialibus legibus. It was regarded as the non plus ultra of scholarship in the Justinian era. Every age, our own certainly not excluded, has its own forms of 'scholarly' obscurantism and obfuscation, regarded as highly respectable branches of 'science' and proper 'epistemological discourse' by contemporaries, but condemned as absolute humbug by later generations. This article is, mainly, on what is currently (at least, we hope so) regarded as humbug. It was taken very seriously though by Justinian and his contemporaries, firm believers in the 'science of numbers' (ars numerorum) and its doctrines. It cannot be seriously maintained that numerology and the arithmetic concerned did not play an important role in the composition of the Digest. Justinian himself explicitly affirmed that it did and we hope to have shown to what extent it was brought into action in what was meant to be the 'pièce de résistance' of Justinian's Digest, 'The Navel'.

49 Of all the 36 books of the Digest that had to be studied by students in Justinian's new curriculum, there are only two with more than 10 titles: D. 1 and D. 2. D. 1 has 22 titles, most of which are rather short titles on the officials of the imperial administration (D. 1,9-1,22). D. 2, however, has a quite different content and no less than 15 titles. It is from here (D. 2) that the compilers of the Digest started to compose that code on the basis of the first part (ta Prota) of Ulpian's commentary ad Edictum. No other book in the mandatory curriculum has more than ten titles. It supports our contention that the last two partes of the Digest (D. 37-44 and D. 45-50) are to be regarded as an appendix (see our previous article (supra, n. 1), p. 515-517), since the amount of titles explodes in these two last partes. There was no connection anymore with the legal curriculum, so the main guiding principle behind the composition of the preceding five partes, the arrangement of the new legal curriculum, had become irrelevant. 